\author{
SERIES 'PROTEOLYTIC ENZYMES AND AIRWAY DISEASES' \\ Edited by J.A. Nadel and R.A. Stockley \\ Number 2 in this Series
}

\title{
Regulation of airway neurogenic inflammation by neutral endopeptidase
}

\author{
G.U. Di Maria*, S. Bellofiore**, P. Geppetti+
}

Regulation of airway neurogenic inflammation by neutral endopeptidase. G.U. Di Maria, S. Bellofiore, P. Geppetti. CERS Journals Ltd 1998.

ABSTRACT: Airway neurogenic inflammation is caused by tachykinins released from peripheral nerve endings of sensory neurons within the airways, and is characterized by plasma protein extravasation, airway smooth muscle contraction and increased secretion of mucus.

Tachykinins are degraded and inactivated by neutral endopeptidase (NEP), a membrane-bound metallopeptidase, which is located mainly at the surface of airway epithelial cells, but is also present in airway smooth muscle cells, submucosal gland cells and fibroblasts. The key role of NEP in limiting and regulating the neurogenic inflammation provoked by different stimuli has been demonstrated in a large series of studies published in recent years. It has also been shown that a variety of factors, which are relevant for airway diseases, including viral infections, allergen exposure, inhalation of cigarette smoke and other respiratory irritants, is able to reduce NEP activity, thus enhancing the effects of tachykinins within the airways.

On the basis of these observations, the reduction of neutral endopeptidase activity may be regarded as a factor that switches neurogenic airway responses from their physiological and protective functions to a detrimental role that increases and perpetuates airway inflammation. However, further studies are needed to assess the role of neutral endopeptidase down regulation in the pathogenesis of asthma and other inflammatory airway diseases.

Eur Respir J 1998; 12: 1454-1462.
*Istituto di Malattie dell' Apparato Respiratorio, Università di Catania, Catania, Italy. **Servizio di Fisiopatologia Respiratoria, Ospedale 'M. Ascoli \& S. Tomaselli', Catania, Italy +Dipartimento di Medicina Clinica e Sperimentale, Sezione di Farmacologia, Università di Ferrara, Ferrara, Italy.

Correspondence: G.U. Di Maria, Istituto di Malattie Respiratorie, Università di Catania, Via Passo Gravina 187, 95125 Catania, Italy, Fax: 390957594532

Keywords: Airways, asthma, metabolism, neurogenic inflammation, neutral endopeptidase, tachykinins

Received: December 171997

Accepted for publication January 101998

This work has been supported in part by the National Research Council (CNR) of Italy, grants No. 93.00265.CT04 and 94 02288.CT04
The pathogenesis of chronic inflammatory disorders, such as asthma and chronic bronchitis, is obscure. There is evidence, however, that neural pathways in the airways may be involved in some of the inflammatory responses characterizing these disorders [1]. It has long been recognized that cholinergic parasympathetic nerves play a role in the regulation of airway calibre and secretion of mucus in health and disease [2]. More recently, peptide transmitters released from the peripheral endings of a subset of slowly conducting primary sensory neurons were found to cause many of the inflammatory responses that characterize asthma [3]. These primary sensory neurons, mainly C-fibre and $\mathrm{A} \delta$-fibre polymodal nociceptors, the cell bodies of which are present in the vagal nodose ganglia, supply the conducting airways. The cell bodies of these neurons produce neuropeptides that are transported along the axons and are released from both central and peripheral nerve endings. These neuropeptides are the tachykinins, substance $\mathrm{P}$ (SP) and neurokinin (NK)A, and the calcitonin gene-related peptide (CGRP). Although CGRP is colocalized with SP in some sensory nerves and exerts various effects in different organs and tissues, its role in the airways appears to be restricted to vasodilation of large bronchial arteries.
In recent years, attention has been focused on the possible pathophysiological role of tachykinins in asthma, because SP and NKA cause many of the airway responses observed in this disease as a manifestation of neurogenic inflammation [1]. These responses include bronchoconstriction, submucosal gland secretion, vasodilation, plasma protein extravasation, adhesion of leukocytes to the vascular endothelium, potentiation of cholinergic neurotransmission and cough.

\section{Neurogenic inflammation}

Neurogenic inflammation is regarded as a protective mechanism called into operation whenever noxious conditions or agents threaten homeostasis of the tissue. The activation by sensory nerve fibres of a local inflammatory protective response was proposed a century ago, on the basis of the observation that in the skin of humans and other mammals neurogenic vasodilation in response to noxious stimuli is independent of central connections of sensory nerve fibres $[4,5]$. Subsequently, evidence has accumulated showing that neurogenic inflammation is not restricted to the skin but also occurs in visceral organs, 
including the respiratory tract, eyes, joints and dura mater [6]. The release of sensory neuropeptides from peripheral endings of primary sensory neurons has been referred to as the "efferent" or "local effector" function, as opposed to the afferent (sensory) function of these nerve fibres [7, 8].

The inflammatory response complex, including local vasodilation, plasma protein extravasation, leukocyte and platelet adhesion, and mast cell degranulation, is brought about by neuropeptides released from peripheral endings of sensory neurons upon stimulation of their primary sensory terminals [9]. Sensory neuropeptides, by virtue of their vasodilator action and stimulation of proliferative activity of fibroblasts and endothelial cells $[10,11]$, are considered to play major roles in the maintenance of tissue trophism, as indicated by the occurrence of skin and corneal lesions [12] and the increased incidence of gastric ulceration [13] in animals in which primary sensory neurons were permanently destroyed in the postnatal period. In contrast to these beneficial and protective actions, activation of primary sensory neurons may cause an exaggerated inflammatory response, leading to neurogenic inflammation. This neurogenic inflammation has been proposed to play a role in various chronic diseases, including arthritis, migraine and asthma [14-16].

The mechanisms by which neurogenic inflammatory responses may be exaggerated are multiple. Increased synthesis, release and transport of peptide transmitters have been observed in models of arthritis [17]. An increased number of receptors for tachykinins has been detected in bowel tissue affected by chronic inflammatory disease [18]. In addition to these mechanisms, it is possible that normal levels of released peptides acting on normally functioning receptors cannot be removed efficiently from the milieu, leading to exaggerated responses. Termination of the action of neuropeptides is usually accomplished by enzymatic degradation, whereas dilution and reuptake provide negligible contributions.

The activity of peptides in biological systems can be dramatically changed by increasing or decreasing the rate of hydrolysis of their amino acid bonds by peptidases. The great importance of modulating the action of peptide neurotransmitters and hormones by inhibition of their enzymatic degradation is emphasized by the clinical and therapeutic impact of the discovery of inhibitors of angiotensin-converting enzyme (ACE). During the last two decades, a variety of peptides has been recognized to play pivotal roles in a number of physiological and pathophysiological processes. The identification of enzymes involved in peptide degradation and the discovery of selective inhibitors for these enzymes are of primary importance for disclosing mechanisms of disease, and eventually for the design of new therapeutic modalities. In this perspective, the role of enzymes that are able to cleave and inactivate tachykinins may be of primary importance in shifting neurogenic inflammatory responses from their physiological protective functions to negative and detrimental pathophysiological roles.

\section{Neutral endopeptidase}

Tachykinins may be degraded in vitro by a variety of enzymes, including serine proteases [19], mast cell chymase [20], calpains [21], neutral endopeptidase [22] and
ACE [23]. However, in vivo, responses to tachykinins appear to be modulated mainly by neutral endopeptidase (NEP) and in a few instances by ACE (which is able to cleave SP, but not NKA [23]). Neutral endopeptidase (also known as metalloendopeptidase, E.C.3.4.24.11), first discovered in the brush border epithelium of the kidney [24], is identical to a peptidase isolated from the rat brain and called enkephalinase for its ability to cleave the small opioid peptides Leu- and Met-enkephalin [25]. NEP is also identical to the common acute lymphoblastic leukaemia antigen (CALLA), also called antigen CD10 or gp100 [26].

NEP is a glycosylated zinc metallopeptidase protein, consisting of 749 amino acid residues [27], a short cytoplasmic domain, a hydrophobic domain that anchors the enzymatic molecule to the plasma membrane, and a large extracellular domain containing the active site [28]. Neutral endopeptidase preferentially cleaves peptides on the amino acid site of hydrophobic residues (phenylalanine, leucine, methionine), and hydrolyses the peptide bonds GInPhe, Phe-Phe and Gly-Leu of SP, and Ser-Phe and Gly-Leu of NKA [22]; thus, yielding inactive fragments lacking the carboxyl terminal region, which is necessary for the binding to the tachykinin receptor.

Like other peptidases, NEP is not selective for a given peptide, but it cleaves a variety of substrates of different lengths, including kinins, gastrin-releasing peptide, atrial natriuretic peptide (ANP), enkephalins, endothelins, insulin-B chain, interleukin- $1 \alpha$, and the chemotactic peptide $\mathrm{N}$-formyl-Met-Leu-Phe (fMLP). However, the selectivity of NEP for its substrates is variable. For instance, it has been shown that NEP is very active in cleaving internal peptide bonds of SP, whereas despite its ability to cleave CGRP at several locations, the enzyme to substrate interaction is weak [29]. In addition, despite the ability of NEP to cleave and inactivate a variety of peptides in vitro, a certain specificity is observed in vivo, probably determined by the expression and tissue distribution of NEP and by the distribution of its potential substrates.

Thus, because NEP, tachykinins and tachykinin receptors are widely present in airway tissues of different animal species, many researchers have paid attention to the importance of NEP in modulating airway responses to tachykinins. In this article, we will review the evidence for the role of NEP in regulating airway responses to tachykinins, and we will discuss the putative role of airway sensory nerves and neurogenic inflammation in the pathogenesis of asthma.

\section{Effect of NEP inhibition on airway responses to tachy- kinins and neurogenic inflammation}

The initial observation that NEP inhibitors potentiate the macromolecule secretion evoked by SP from submucosal glands of the ferret trachea $[30,31]$ provided the hypothesis that NEP may be important in the regulation of airway responses to exogenously administered tachykinins. This observation also raised the possibility that NEP metabolism is of critical importance in modulating the activity of endogenously released tachykinins, and hence of neurogenic inflammation [1]. These ideas were proven to be true in a large series of in vitro and in vivo studies based on the use of NEP inhibitors, thiorphan and phosphoramidon, and of recombinant NEP (rNEP) in a series of experimental models. The secretion of mucus from submucosal 
glands, evoked by exogenous tachykinins, is mediated by $\mathrm{NK}_{1}$ receptors and is markedly potentiated by NEP inhibitors. This effect has been observed in several mammalian species, including human [32, 33].

Tachykinins potently contract airway smooth muscle. This contractile response is mediated mainly by $\mathrm{NK}_{2}$ receptors and is regulated by NEP activity. Evidence for this regulation is provided by the observation that NEP inhibition by phosphoramidon shifts the concentration-response curve to NKA and SP to the left in guinea-pig [31], ferret [34] and human airway smooth muscle [35]. Similarly, the suppression of NEP activity potentiates the increase in total pulmonary resistance caused by tachykinins in guineapigs [36] and humans [37, 38]. In guinea-pigs, bronchoconstriction in response to inhaled SP is accompanied by cough, an effect which is also increased by NEP inhibition and decreased by pretreatment with aerosolized rNEP [39].

Exudation of a protein-rich plasma into the affected tissues is a key feature of airway neurogenic inflammation [40] and SP is exceedingly potent in causing increased vascular permeability in rodent airways [41]. All of these effects of SP are exaggerated by the suppression of NEP activity [42], and are reduced or abolished by SP antagonists $[43,44]$. Hence, it is quite reasonable to postulate that NEP modulates the activity of SP on airway vascular permeability and plasma exudation that occur in rodents in response to airway irritants. Finally, it has been demonstrated that NEP inhibitors potentiate other important aspects of airway neurogenic inflammation, including SPinduced increase in cholinergic neurotransmission [34], and vasodilation evoked by tachykinins in the rat airway microcirculation [45].

Altogether, these findings provide powerful evidence that tachykinins released from sensory nerves mediate multiple effects in the airways, and that NEP activity may modulate effects of tachykinins in a variety of target cells. It has also been reported that the inhibition of NEP caused by aerosolized phosphoramidon is accompanied by a significant increase in airway smooth muscle tone in asthmatic subjects; thus, suggesting that tachykinins and NEP may participate in the regulation of resting airway calibre [46]. However, these observations conflict with previous results obtained using a similar experimental approach [38]. A more recent study demonstrates that NEP inhibition by inhaled thiorphan does not affect resting airway calibre in asthma [47].

There is a large body of evidence that NEP also modulates the airway response to endogenously released tachykinins. Electrical stimulation of the vagus nerves or administration of capsaicin, the pungent agent contained in the plants of the genus Capsicum, release tachykinins from sensory nerve endings and evoke a complex response in the airways, that includes vasodilation, plasma protein extravasation, leukocyte adhesion, cough, noncholinergic bronchoconstriction, and secretion of mucus [48-51]. The noncholinergic contraction of guinea-pig bronchi evoked by electrical field stimulation [52] and other airway responses mediated by endogenously released tachykinins $[53,54]$ are potentiated by the NEP inhibitors, phosphoramidon and leucine-thiorphan. Interestingly, in human isolated small bronchi, capsaicin causes a mild contractile effect that is evident after NEP inhibition [55]. The observation that the NEP inhibitor, thiorphan, potentiates bronchoconstriction in response to inhaled sodium metabisulphite in normal subjects [56] provides circumstantial evidence that bronchoactive NEP substrates are released in human airways in response to sodium metabisulphite, and that NEP modulates the airway response to this indirect bronchoconstrictor agent.

A number of different stimuli has been shown to release sensory neuropeptides from peripheral endings of sensory neurons. These include alterations of the internal milieu, such as changes in hydrogen ion concentration or osmolarity, recreational or industrial pollutants, such as cigarette smoke or toluene diisocyanate (TDI) irritants such as mustard oil, and pro-inflammatory mediators, including bradykinin, histamine, peptidoleukotrienes, prostanoids, platelet-activating factor (PAF), eosinophil cationic protein (ECP), and lipoxins [7, 32, 57]. NEP inhibitors have been repeatedly shown to increase the release of tachykinins and to exaggerate the neurogenic inflammatory responses evoked by these mediators.

\section{Distribution of sensory nerves, tachykinin receptors and NEP in the airways}

Critical factors that govern specificity in the enzymatic degradation of endogenously released peptides are the tissue distribution of the enzyme peptidase and that of its substrate. The skeletal neuromuscular junction forms a specialized unit, in which acetylcholinesterase clusters with nicotinic receptors are in close proximity to the nerve terminal. Sensory nerve endings and effector cells expressing tachykinin receptors do not appear to be arranged in a similar manner. There is no evidence of a specialized unit between the sensory nerve terminal and effector cells, and the sensory peptide transmitter is presumed to diffuse from the site of release to the site of action. Peptidases specifically involved in the cleavage of sensory neuropeptides may be located at any site between these two points. It is also possible that the peptidase is colocalized in the same cells as the tachykinin receptors, and that both of these entities compete for agonist-binding. This latter hypothesis is supported by the observation that the response to $\mathrm{SP}$ is smaller in cells expressing both $\mathrm{NK}_{1}$ receptors and NEP than in cells expressing only the $\mathrm{NK}_{1}$ receptor or NEP [58].

Sensory nerves containing tachykinins make a dense network of fibres beneath the epithelium of rodent airways [59]. Sensory nerves fibres are also present in the vicinity of smooth muscle cells and submucosal gland cells and around arterial vessels, whereas they are apparently absent around venules [59]. In human tissues, SPcontaining sensory nerves are less abundant than in rodents, but they exhibit a similar pattern of distribution [60, 61]. Morphological [62] and functional evidence [32] indicates the presence of $\mathrm{NK}_{1}$ or $\mathrm{NK}_{2}$ receptors for tachykinins in submucosal glands, in endothelial and smooth muscle cells.

The distribution of NEP has been examined by means of specific antibodies, by measuring its activity, or by its labelling with selective inhibitors. NEP is conspicuously present in the kidney, lungs, discrete brain regions, reproductive organs, bone marrow, intestine and lymph nodes [28]. The broad substrate specificity and the almost ubiquitous distribution of NEP suggest roles in the cleavage of 
different peptides involved in several functions. In the lungs, NEP is abundantly expressed in epithelial cells [63]. Less, although functionally relevant, NEP has been found in fibroblasts, smooth muscle cells and submucosal gland cells [63]. The presence of NEP in the target cells for tachykinin action, such as fibroblasts and smooth muscle cell explains why even after the removal of the major source of NEP (e.g. the epithelium) NEP inhibitors still potentiate the nonadrenergic noncholinergic contraction evoked by electrical stimulation or by capsaicin [52].

It is possible that tachykinins released from sensory nerve terminals are cleaved by NEP, either during their diffusion through the tissue or at effector cell sites. Because of the high concentration of NEP in the epithelium, it is not surprising that removal of epithelium leads to potentation of the bronchoconstrictor responses evoked by exogenous tachykinins [52]. Shedding of epithelial cells is commonly found in bronchial biopsies of patients with severe asthma [64]. Reduction of peptidase activity in epithelial cells by various agents known to aggravate asthma has also been reported [65-67]. These observations are of particular interest, because they depict a possible scenario for the involvement of exaggerated neurogenic inflammatory responses as a consequence of decreasing NEP activity in asthma [68]. Moreover it has recently been shown that NEP expression in the airway epithelium of bronchial biopsies from atopic asthmatics is inversely related both to asthma symptoms and to bronchial hyperresponsiveness [69]. This observation provides further circumstantial evidence that decreased NEP activity may be involved in the occurrence of asthma symptoms and airway hyperresponsiveness.

\section{NEP modulates neurogenic inflammation evoked by different stimuli}

A number of stimuli causes neurogenic inflammation in the airways. Some of them bear a particular relevance for human diseases. The industrial pollutant, TDI, is the causative agent of a form of occupational asthma. The mechanisms by which TDI causes asthma are not well understood, but there is evidence that TDI contracts guinea-pig bronchial smooth muscle by releasing tachykinins from sensory nerve endings [70]. Similarly, cigarette smoke inhalation produces a remarkable plasma protein extravasation in the airway mucosa of rodents, which is completely abolished by chemical denervation of sensory neurons with capsaicin or by blockade of $\mathrm{NK}_{1}$ tachykinin receptors [49]. Increased tonicity of the fluid covering the epithelium is considered to be the stimulus that triggers exercise-induced asthma [71]. Hypertonic media release sensory neuropeptides, and thus evoke inflammatory responses in the airways [72]. The observation that NEP inhibitors potentiate these effects indicates the ability of NEP to limit inflammation caused by these agents.

Inhalation of allergens is a common cause of airway narrowing and inflammation in asthmatic patients. The involvement of neurogenic inflammation in the bronchomotor and inflammatory responses to allergen has been extensively evaluated in experimental animals, using different experimental approaches based on sensory denervation with high doses of capsaicin, NEP inhibition, or highly selective nonpeptide antagonists for $\mathrm{NK}_{1}[73]$ and $\mathrm{NK}_{2}[74]$ tachykinin receptors. Allergen inhalation causes protein plasma extravasation and increases total pulmonary resistance in sensitized guinea-pigs. Both the vascular and the bronchomotor responses to allergen are potentiated by NEP inhibition and are reduced by tachykinin receptor antagonists [75-78]. These observations suggest that mediators released from airway inflammatory cells in response to antigen activate sensory nerves to release neuropeptides that contribute to airway narrowing and plasma extravasation. When NEP activity is inhibited, tachykinins are less rapidly inactivated and accumulate in the tissue, thus contributing to the exaggerated responses. This interpretation is further supported by the observation that ovalbumin-induced plasma extravasation in the nasal mucosa of sensitized guinea-pigs is decreased by the $\mathrm{NK}_{1}$ receptor antagonist and is increased by the NEP inhibitor phosphoramidon [79].

In contrast to these data in rodents, recent data have shown that inhalation of the NEP inhibitor, thiorphan, does not affect either the early or the late asthmatic bronchoconstriction to allergen inhalation in asthmatic subjects, suggesting that tachykinins may not be involved in these allergic asthmatic responses in humans [47].

A key role for NEP in the control of inflammation in different organs has recently been demonstrated [80]. In mice in which the gene coding NEP has been disrupted by homologous recombination and gene-targeting (NEP knockout mice), baseline increased levels of plasma extravasation were observed in skin, airway, gastrointestinal and urinary tract tissue [80]. The increase in plasma extravasation was completely abolished by a tachykinin $\mathrm{NK}_{1}$ receptor antagonist and by a bradykinin $\mathrm{B}_{2}$ receptor antagonist. These observations support the hypothesis that NEP downregulation results in increased kinin levels, leading to inflammation in several tissues, including airways.

Another mechanism by which NEP could achieve bronchoprotection in asthma is suggested by the study of $\mathrm{H}_{\text {ARRI- }}$ Son et al. [81]. These authors demonstrated that the NEP inhibitor, phosphoramidon, enhanced human fibroblast proliferation in a dose-dependent manner, thus suggesting that the structural abnormalities enhanced by neuropeptides are modulated by NEP.

\section{Role of NEP in the metabolism of kinins}

Because kininogens and kallikrein are present in the airways and because these molecules [82], as well as kinins, are increased in the bronchoalveolar lavage fluid from asthmatics challenged with allergen [83, 84], kinins have been suspected to play important roles in asthma [85]. Bradykinin is an algesic agent that causes inflammatory responses by acting directly on specific receptors in effector cells and indirectly by releasing a variety of agents [86], including sensory neuropeptides [87]. When applied locally to the airways, bradykinin causes plasma extravasation and bronchoconstriction, mainly by activating cholinergic reflexes and releasing tachykinins from sensory nerves endings [88]. Although bradykinin is cleaved by $\mathrm{ACE}$ and NEP $[22,23]$, increased total pulmonary resistance and airway wall oedema caused by local application of bradykinin are exaggerated following NEP inhibition $[89,90]$. The observation that bradykinin $\mathrm{B}_{2}$ receptor an-tagonists and tachykinin $\mathrm{NK}_{1}$ receptor antagonists are equally potent in reducing antigen-evoked 
plasma extravasation indicates that kinins that are released by antigen activate sensory nerves [75].

Bradykinin also increases vascular permeability in human upper airways [91], and causes bronchoconstriction in asthmatics, in part by activating cholinergic reflexes [92]. A mixed antagonist for $\mathrm{NK}_{1}$ and $\mathrm{NK}_{2}$ receptors has been shown to reduce bronchoconstriction in response to inhaled bradykinin in asthmatics, thus suggesting that part of the bradykinin-evoked increase in total pulmonary resistance is due to local release of tachykinins [46-93]. These observations indicate that kinins activate inflammatory and bronchomotor responses in human airways, involving the release of tachykinins and similar to those observed in experimental animals. However, further studies are needed to establish whether this pharmacological information has pathophysiological relevance in the mechanism of human allergic diseases.

\section{Conditions that affect airway NEP activity}

There is a growing evidence that NEP activity can be affected by a variety of factors. Reduction in NEP activity leads to exaggeration of the inflammatory response evoked by peptides released from peripheral endings of sensory nerves. Therefore, NEP downregulation may be regarded as a factor that switches neurogenic inflammation from its physiological trophic and protective function to a detrimental role that increases or perpetuates the severity of different disease states.

Several studies have suggested that a number of pathogens, including Sendai virus and influenza virus, and respiratory irritants, including cigarette smoke, TDI, hypochlorous acid and acrolein, can decrease airway NEP activity. In rats with respiratory infections, it has been shown that plasma extravasation induced by SP is markedly increased and that the NEP inhibitor, thiorphan, significantly potentiates SP-induced plasma extravasation in pathogen-free rats but not in infected rats, suggesting a reduction of NEP activity in the airways of the infected animals $[42,66]$. This evidence is further supported by the observation of a significantly lower content of NEP in airways obtained from infected rats [42].

Cigarette smoke causes airway inflammation and hyperresponsiveness in humans. It has been shown that cigarette smoke causes neurogenic inflammation through the release of endogenous tachykinins [49]. By showing that cigarette smoke solution inhibits NEP activity from guineapig tracheal homogenates in a concentration-dependent manner, Dusser et al. [67] further extended the knowledge of the mechanism by which cigarette smoke causes neurogenic inflammation. These findings have been confirmed by the recent observation showing that airway plasma extravasation induced by smoke inhalation in guinea-pigs is blocked by an $\mathrm{NK}_{1}$ receptor antagonist, and it is potentiated by the NEP inhibitor, phosphoramidon [94].

TDI and hypochlorous acid decrease NEP activity and selectively potentiate tachykinin-evoked responses in guineapig airways [65]. Recently, it has been shown that sulphur mustard, an alkylating agent causing airway irritation and asthma-like symptoms, decreases NEP activity in the tracheal epithelium of the guinea-pig [95]. A similar inhibitory effect on NEP activity is exerted by hydrogen peroxide [96]. Because it is widely recognized that viral infections, cigarette smoke and industrial or air pollutants cause asthma exacerbations, these observations further support the hypothesis that NEP and neurogenic inflammation are involved in the pathogenesis of asthma.

It has been hypothesized that corticosteroids are able to increase the activity and the expression of NEP. This hypothesis is supported by the observations that glucocorticoids increase the expression of NEP in transformed epithelial cells from human bronchi [97], and markedly reduce neurogenic plasma extravasation in rat airways [98]. However, a recent study provides evidence against the upregulating effect of glucocorticoids on NEP activity, because dexamethasone decreased plasma extravasation induced by capsaicin without affecting NEP activity in the rat trachea [99]. Consistent with the hypothesis that glucocorticosteroids upregulate NEP in the airways is the finding that NEP expression is enhanced in airway epithelium from atopic asthmatic patients who regularly use inhaled glucocorticosteroids [69].

\section{Other pathophysiological roles of NEP in the lung}

A variety of peptides are produced in the lungs or delivered to the lungs from the circulation or via the airways. NEP contained in airway epithelial cells or in vascular endothelial cells may have an important role in the metabolism of these peptides and may affect their function.

The $N$-formylated oligopeptides, produced by bacteria, are potent chemotactic agents for neutrophils and contribute to the neutrophilic inflammatory response to bacteria. Because fMLP is cleaved by NEP [28], it has been hypothesized that NEP is involved in the regulation of the inflammatory response to bacterial infections in the airways. Evidence for this hypothesis is provided by the observation that inhibition of NEP present in the cell membrane of neutrophils potentiates the chemoattractant activity of fMLP [100].

Bombesin-like peptides, including the mammalian gastrin-releasing peptide (GRP), are potent mitogens for normal bronchial epithelial cells and neuroendocrine cells. Small cell lung cancer, which is considered to be derived from the transformation of neuroendocrine cells, also responds to these peptides. An autocrine loop exists in the small cell carcinomas that secrete bombesin-like peptides, express bombesin receptors and are stimulated to proliferate by these peptides [101]. Neutral endopeptidase efficiently cleaves GRP. The growth of bombesin-like peptide-dependent carcinomatous cells is blocked by NEP and is increased by NEP inhibition [101]. Because cigarette smoke inactivates bronchial epithelial cell surface NEP and small cell carcinomas occur almost exclusively in cigarette smokers, it has been hypothesized that the cigarette smokedependent decrease in NEP activity may be causally related to the proliferation of small cell carcinomas of the lung [101, 102].

Endothelins are potent vasoconstrictor peptides produced by endothelial cells. Endothelin-1 may be also produced by bronchial epithelial cells [103], and causes contraction of airway smooth muscle of guinea-pigs [104] and humans [105]. NEP cleaves endothelins [106]. The observations that removal of the endothelium and NEP inhibition increase the bronchomotor response to endothelin-1, whereas recombinant human NEP reduces the response to endo- 
thelin, indicate that NEP plays a major role in the metabolism of endothelin-1 [107]. These observations have recently been confirmed and extended [108]. The finding of increased expression of endothelin immunoreactivity in the epithelial cells of asthmatics [109] indicates the possible role of endothelins and their cleavage in diseases that lead to airway narrowing.

\section{Concluding remarks}

In the treatment of asthma, there are some limited options. The relief from bronchoconstriction is commonly achieved by $\beta_{2}$-adrenergic agonists, which act directly on airway smooth muscle, whereas airway inflammation, which is a prominent feature of asthma, is controlled by "nonspecific" anti-inflammatory drugs, such as corticosteroids. These considerations emphasize the inadequacy of our current understanding of the pathophysiology of asthma. Accordingly, therapy is not usually targeted selectively to the causal mechanism of the symptoms. It is probable that many factors contribute to the development of disease, either acting independently or arranged in a cascade of events. The release of peptide transmitters from sensory nerve endings by exogenous or endogenous stimuli, by provoking neurogenic inflammation, may be part of this cascade.

NEP may play a central role in the mechanisms governing the integrity of the airways and the modulation of airway neurogenic inflammation in asthma and other inflammatory disorders of the airways. Sensory nerve activation usually exerts a protective action for the integrity of the tissue against injury. Cigarette smoke, hypertonicity of the tracheobronchial fluid, air pollutants, antigen and endogenous mediators released by these stimuli may activate this protective function. However, when NEP is downregulated or when the airway epithelium (which contains measurable amounts of NEP) is damaged, the unopposed action of sensory neuropeptides may lead to exaggerated inflammation.

The discovery of selective and potent antagonists of tachykinin receptors, suitable for use in human studies, will provide the opportunity to test the validity of this hypothesis in a clinical setting. Strategies directed to increase the action of neutral endopeptidase, including the administration of recombinant neutral endopeptidase, may have relevance for the treatment of airway disorders.

Acknowledgments: The authors wish to thank J.A. Nadel for thoughtful discussion and helpful advice.

\section{References}

1. Nadel JA. Neutral endopeptidase modulates neurogenic inflammation. Eur Respir J 1991; 4: 745-754.

2. Widdicombe JG, Karlsson JA, Barnes PJ. Cholinergic mechanisms in bronchial hyperresponsiveness and asthma. In: Kaliner MA, Barnes PJ, Persson CGA, eds. Asthma: Its Pathology and Treatment. New York, Dekker, 1991; pp.327-356

3. Lundberg JM. Tachykinins, sensory nerves and asthma: an overview. Can J Physiol Pharmacol 1995; 73: 908914.
4. Bruce AN. Vasodilator axon reflexes. $Q J$ Exp Physiol 1913; 6: 339-354.

5. Bayliss WM. On the origin from the spinal cord of the vasodilator fibres of the hind limb, and the nature of these fibres. J Physiol 1901; 26: 173-209.

6. Jancso N, Jancso-Gabor A, Szolcsany J. Direct evidence for neurogenic inflammation and its prevention by denervation and by pretreatment with capsaicin. Br J Pharmacol Chemother 1967; 31: 138-151.

7. Holzer P. Capsaicin: cellular targets, mechanisms of action, and selectivity for thin sensory neurons. Pharmacol Rev 1991; 43: 143-201.

8. Szolcsanyi J. Capsaicin-Sensitive Chemoceptive Neural System with Dual Sensory-Efferent Function. Budapest, Akademiai Kiado, 1984: pp. 27-52.

9. Jancso N, Jancso-Gabor A, Szolcsanyi J. The role of sensory nerve endings in neurogenic inflammation induced in human skin and in the eye and paw of the rat. $\mathrm{Br} \mathrm{J}$ Pharmacol 1968; 32: 32-41.

10. Nilsson J, Von Euler AM, Dalsgaard CJ. Stimulation of connective tissue cell growth by substance $\mathrm{P}$ and substance K. Nature 1985; 315: 61-63.

11. Ziche M, Morbidelli L, Pacini M, Geppetti P, Alessandri G, Maggi CA. Substance P stimulates neovascularization in vivo and proliferation of cultured endothelial cells. Microvasc Res 1990, 40: 264-278.

12. Maggi CA, Borsini F, Santicioli P. Cutaneous lesions in capsaicin-pretreated rats. A trophic role of capsaicin-sensitive afferents? Naunyn Schmiedeberg's Arch Pharmacol 1987; 336: 538-545.

13. Holzer P, Sametz W. Gastric mucosal protection against ulcerogenic factors in the rat mediated by capsaicin-sensitive afferent neurons. Gastroenterology 1986; 91: 975981.

14. Barnes PJ. Asthma as an axon reflex. Lancet 1986; i: 242-245.

15. Moskowitz MA. The neurobiology of vascular head pain. Ann Neurol 1984; 16: 157-168.

16. Levine J, Collier D, Basbaum A, Moskowitz M, Helms C. Hypothesis: the nervous system may contribute to the pathophysiology of rheumatoid arthritis. J Rheumatol 1984; 12: 406-411.

17. Lembeck F, Donnerer J, Copaert FC. Increase in substance P primary afferent nerves during chronic inflammation. Neuropeptides 1981; 1: 175-180.

18. Manthy CR, Gates TS, Zimmermann RP, et al. Receptor-binding sites for substance $\mathrm{P}$ but not substance $\mathrm{K}$ or neuromedin $\mathrm{K}$ are expressed in high concentrations by arterioles, venules and lymph nodules in surgical specimens obtained from patients with ulcerative colitis and Crohn's disease. Proc Natl Acad Sci USA 1988; 85: 3235-3239.

19. Hanson GR, Lovenberg W. Elevation of substance P-like immunoreactivity in the rat central nervous system by protease inhibitors. J Neurochem 1980; 35: 1370-1374.

20. Caughey GH, Leidig F, Viro NF, Nadel JA. Substance P and vasoactive intestinal peptide degradation by mast cell tryptase and chymase. J Pharmacol Exp Ther 1988; 244: 133-137.

21. Murachi T, Hatanaka M, Hakamoto T. Calpains and neuropeptide metabolism. In: Turner AJ, ed. Neuropeptides and their Peptidases. Chichester, UK, Ellis Horwood Ltd, 1987; pp. 202-228.

22. Turner AJ. Endopeptidase-24.11. In: Turner AJ, ed. Neuropeptides and their Peptidases. Chichester, UK, Ellis Horwood, 1987; pp. 315-333.

23. Skidgel RA. Bradykinin-degrading enzymes: structure, 
function, distribution, and potential roles in cardiovascular pharmacology. J Cardiovasc Pharmacol 1992; 20: S4-S9.

24. Kerr MA, Kerney AJ. The purification and specificity of a neutral endopeptidase from rabbit kidney brush border. Biochem J 1974; 137: 477-488.

25. Malfroy B, Swerts JP, Guyon A, Roques BP, Schwartz JC. High-affinity enkephalin-degrading peptidase in mouse brain and its enhanced activity following morphine. Nature 1978; 276: 523-526.

26. Crossman J, Neckers LM, Leonard WJ, Greene WC. Polymorphonuclear neutrophils express the common ac-ute lymphoblastic leukemia antigen. J Exp Med 1983; 157: 1064-1069.

27. Devault A, Lazure C, Nault C, et al. Amino acid sequence of rabbit kidney neutral endopeptidase 24.11 (enkephalinase) deduced from complementary DNA. EMBO J 1987; 6: 1317-1322.

28. Roques BP, Noble F, Dauge V, Fournie-Zaluski M-C, Beaumont A. Neutral endopeptidase 24.11: structure, inhibition, and experimental and clinical pharmacology. Pharmacol Rev 1993; 45: 87-146.

29. Katayama M, Nadel JA, Bunnett NW, Di Maria GU, Haxhiu M, Borson DB. Catabolism of calcitonin gene-related peptide and substance $\mathrm{P}$ by neutral endopeptidase. Peptides 1991; 12: 563-567.

30. Borson DB, Corrales R, Varsano S, et al. Enkephalinase inhibitors potentiate substance P-induced secretion of ${ }^{35} \mathrm{SO}_{4}$ macromolecules from ferret trachea. Exp Lung Res 1987; 12: 21-36.

31. Stimler-Gerard NP. Neutral endopeptidase-like enzyme controls the contractile activity of susbtance $\mathrm{P}$ in guineapig lung. J Clin Invest 1987; 79: 1819-1825.

32. Geppetti P, Bertrand C, Bacci E, Huber O, Nadel JA. Characterization of tachykinin receptors in the ferret trachea by peptide agonists and nonpeptide antagonists. Am J Physiol 1993; 265: L164-L169.

33. Rogers DF, Aursudkij B, Barnes PJ. Effects of tachykinins on mucus secretion on human bronchi in vitro. Eur $J$ Pharmacol 1989; 174: 283-286.

34. Sekizawa K, Tamaoki J, Nadel AJ, Borson DB. Enkephalinase inhibitor potentiates substance $\mathrm{P}$-and electrically-induced contraction in ferret trachea. J Appl Physiol 1987; 63: 1401-1405.

35. Naline E, Devillier P, Drapeau G, et al. Characterization of neurokinin effects and receptor selectivity in human isolated bronchi. Am Rev Respir Dis 1989; 140: 679-686.

36. Dusser DJ, Umeno E, Graf PD, Djokic T, Borson DB, Nadel JA. Airway neutral endopeptidase-like enzyme modulates tachykinin-induced bronchoconstriction in vivo. $J$ Appl Physiol 1988; 65: 2585-2591.

37. Cheung D, Bel EH, Denhartigh J, Dijkman JH, Sterk PJ. The effect of inhaled neutral endopeptidase inhibitor, thiorphan, on airway responses to neurokinin A in normal humans in vivo. Am Rev Respir Dis 1993; 145: 12751280.

38. Crimi N, Palermo F, Oliveri R, Polosa R, Magri S, Mistretta A. Inhibition of neutral endopeptidase potentiates bronchoconstriction induced by neurokinin-A in asthmatic patients. Clin Exp Allergy 1994; 24: 115-119.

39. Kohroghi H, Nadel JA, Malfroy B, et al. Recombinant human enkephalinase (neutral endopeptidase) prevents cough induced by tachykinins in awake guinea-pigs. $J$ Clin Invest 1989; 84: 781-786.

40. Lundberg JM, Saria A. Polypeptide-containing neurons in airway smooth muscle. Annu Rev Physiol 1987; 49; 557-572.

41. Saria A, Lundberg JM, Skofitsch G, Lembeck F. Vascular protein leakage in various tissues induced by substance $\mathrm{P}$, capsaicin, bradykinin, serotonin, histamine and by antigen challenge. Naunyn Schmideberg's Arch Pharmacol 1983; 324: 212-218.

42. Borson DB, Brokaw JJ, Sekizawa K, McDonald DM, Nadel JA. Neutral endopeptidase and neurogenic inflammation in rats with respiratory infections. J Appl Physiol 1989; 66: 2653-2658.

43. McDonald DM. Neurogenic inflammation in the respiratory tract: actions of sensory nerve mediators on blood vessels and epithelium of the airway mucosa. Am Rev Respir Dis 1987; 136: S65-S72.

44. Nadel JA. Regulation of neurogenic inflammation by neutral endopeptidase. Am Rev Respir Dis 1992; 145: S48-S52.

45. Yamawaki I, Geppetti P, Bertrand C, et al. Virus infection potentiates the increase in airway blood flow produced by substance P. Am Rev Respir Dis 1993; 148: 657-661.

46. Crimi N, Polosa R, Pulvirenti G, et al. Effect of an inhaled neutral endopeptidase inhibitor, phosphoramidon, on baseline airway calibre and bronchial responsiveness to bradykinin in asthma. Thorax 1995; 50: 505-510

47. Diamant Z, Van der Veen H, Kuijpers EA, Bakker PF, Sterk PJ. The effect of inhaled thiorphan on allergen-induced airway responses in asthmatic subjects. Clin Exp Allergy 1996; 26: 525-532.

48. McDonald DM. Neurogenic inflammation in the rat trachea. I. Changes in venules, leukocytes and epithelial cells. J Neurocytol 1988; 17: 583-603.

49. Lundberg J, Saria A. Capsaicin-induced desensitization of the airway mucosa to cigarette smoke, mechanical and chemical irritants. Nature 1983; 302: 251-253.

50. Piedimonte G, Hoffman JIE, Husseini WK, Hiser WK, Nadel JA. Effect of neuropeptides released from sensory nerves on blood flow in the rat airway microcirculation. $J$ Appl Physiol 1992; 72: 1563-1570.

51. Lundberg JM, Saria A, Brodin E, Rosell S, Folkers K. A substance $\mathrm{P}$ antagonist inhibits vagally-induced increase in vascular permeability and bronchial smooth muscle contraction in the guinea-pig. Proc Natl Acad Sci 1983; 80: $1120-1124$.

52. Djokic TD, Nadel JA, Dusser DJ, Sekizawa K, Graf PD, Borson DB. Inhibitors of neutral endopeptidase potentiate electrically- and capsaicin-induced noncholinergic contractions in guinea-pig bronchi. $J$ Pharmacol Exp Ther 1989; 248: 7-11.

53. Dusser DJ, Nadel JA, Graf PD, Borson DB. Neutral endopeptidase and angiotensin-converting enzyme inhibitors potentiate kinin-induced contraction of ferret trachea. J Pharmacol Exp Ther 1988; 244: 531-536.

54. Umeno E, Nadel JA, Huang H-T, McDonald DM. Inhibition of neutral endopeptidase potentiates neurogenic inflammation in the rat trachea. J Appl Physiol 1989; 66: 2647-2652.

55. Honda I, Kohrogi H, Yamanuchi T, Ando M, Araki S. Enkephalinase inhibitor potentiates substance P- and capsaicin-induced bronchial smooth muscle contractions in humans. Am Rev Respir Dis 1991; 143: 1416-1418.

56. Bellofiore S, Caltagirone F, Ciancio N, Pennisi A, Mistretta A, Di Maria GU. Neutral endopeptidase inhibitor, thiorphan, increases airway narrowing to inhaled sodium metabisulphite in normal subjects. Am J Respir Crit Care Med 1994; 150: 853-856.

57. Maggi CA. The pharmacology of the efferent function of sensory nerves. J Auton Pharmacol 1991; 11: 173-208.

58. Okamoto A, Payan DG, Bunnett NW. Interactions between neutral endopeptidase (NEP, EC 3.4.24.11) and the 
substance $\mathrm{P}$ receptor (SPR, NK-1) expressed in mammalian cells. Gastroenterology 1993; 104: A560.

59. Baluk P, Nadel JA, McDonald DM. Substance P immunoreactive axons in the rat respiratory tract: a quantitative study of their distribution and role in neurogenic inflammation. J Comp Neurol 1992; 319: 586-598.

60. Lundberg JM, Hokfelt T, Martling CR, Saria A, Cuello CA. Substance P immunoreactive sensory nerves in the lower respiratory tract of various mammals including man. Cell Tissue Res 1984; 235: 251-261.

61. Polak JM, Bloom SR. Regulatory peptides and neuronspecific enolase in the respiratory tract of man and other mammals. Exp Lung Res 1982; 3: 313-328.

62. Castairs JR, Barnes PJ. Autoradiographic mapping of substance P receptors in lung. Eur J Pharmacol 1986; 127 : 295-296.

63. Johnson AR, Asthon J, Schls WW, Erdos EG. Neutral endopeptidase in human lung tissue and cultured cells. Am Rev Resp Dis 1985; 132: 564-568.

64. Dunnill MS. The pathology of asthma with special references in the bronchial mucosa. J Clin Pathol 1960; 13: 27-33.

65. Sheppard D, Thompson J, Scypinski L, Dusser D, Nadel J, Borson D. Toluene diisocyanate increases airway responsiveness to substance $\mathrm{P}$ and decreases airway neutral endopeptidase. J Clin Invest 1988; 81: 1111-1116.

66. Jacoby DB, Tamaoki J, Borson DB, Nadel JA. Influenza infection causes airway hyperresponsiveness by decreasing enkephalinase. J Appl Physiol 1988; 64: 2653-2658.

67. Dusser DJ, Djokic TD, Borson DB, Nadel JA. Cigarette smoke induces bronchoconstrictor hyperresponsiveness to substance $\mathrm{P}$ and inactivates airway neutral endopeptidase in guinea-pig. J Clin Invest 1989; 84: 900-906.

68. Nadel JA. Decreased neutral endopeptidase: possible role in inflammatory diseases of airways. Lung 1990; 168 (Suppl.): 123-127.

69. Sont JK, van Krieken JH, van Klink HC, et al. Enhanced expression of neutral endopeptidase (NEP) in airway epithelium in biopsies from steroid- versus nonsteroid-treated patients with atopic asthma. Am J Respir Cell Mol Biol 1997; 16: 549-556.

70. Mapp CE, Boniotti A, Chitano P, et al. The effect of phosphoramidon and epithelium removal on toluene diisocyanate-induced contractions in guinea-pig bronchi. Eur Respir J 1992; 5: 331-333.

71. Smith CM, Anderson SD. Hyperosmolarity as the stimulus to asthma-induced hyperventilation. J Allergy Clin Immunol 1986; 77: 729-736.

72. Umeno E, McDonald DM, Nadel JA. Hypertonic saline increases vascular permeability in the rat trachea by producing neurogenic inflammation. J Clin Invest 1990; 85 : 1905-1908.

73. Snider RM, Constantine JW, Lowe IW, et al. A potent nonpeptide antagonist of the substance $\mathrm{P}\left(\mathrm{NK}_{1}\right)$ receptor. Science 1991; 251: 435-437.

74. Emonds-Alt X, Vilain P, Goulaouic P, et al. A potent and selective nonpeptide antagonist of the neurokinin A $\left(\mathrm{NK}_{2}\right)$ receptor. Life Sci 1992; 50: 101-106.

75. Bertrand C, Geppetti P, Baker J, Yamawaki I, Nadel JA. Role of neurogenic inflammation in antigen-induced vascular extravasation in guinea-pig trachea. J Immunol 1993; 150: 1479-1485.

76. Bertrand C, Geppetti P, Graf PD, Foresi A, Nadel JA. Involvement of neurogenic inflammation in antigen-induced bronchoconstriction in guinea-pigs. Am J Physiol 1993; 265: L507-L511.

77. Bertrand C, Geppetti P. Tachykinin and kinin receptor antagonists: therapeutic perspectives in allergic airway disease. Trends Pharmacol Sci 1996; 17: 255-259.

78. Ricciardolo FLM, Nadel JA, Graf PD, Bertrand C, Yoshihara S, Geppetti G. Role of kinins in anaphylacticinduced bronchoconstriction mediated by tachykinins in guinea-pigs. Br J Pharmacol 1994; 113: 508-512.

79. Ricciardolo FLM, Nadel JA, Bertrand C, Yamawaki I, Chan B, Geppetti G. Tachykinins and kinins in antigenevoked plasma extravasation in guinea-pig nasal mucosa. Eur J Pharmacol 1994; 261: 127-132.

80. Lu B, Figini M, Emanueli C. The control of microvascular permeability and blood pressure by neutral endopeptidase. Nat Med 1997; 3: 904-907.

81. Harrison NK, Dawes KE, Kwon OJ, Barnes PJ, Laurent GJ, Chung KF. Effects of neuropeptides on human lung fibroblast proliferation and chemotaxis. Am J Physiol 1995; 268(2 Pt 1): L278-L283.

82. Proud D, Kaplan A. Kinin formation: mechanisms and role in inflammatory disorders. Ann Rev Immunol 1988; 6: 49-84.

83. Christiansen SC, Proud D, Cochrane CG. Detection of tissue kallikrein in the bronchoalveolar lavage fluid of asthmatic subjects. J Clin Invest 1987; 79: 188-197.

84. Christiansen SC, Proud D, Sarnoffs RB, Juergens U, Cochrane CG, Zuraw BL. Elevation of tissue kallikrein and kinin in the airways of asthmatic subjects following endobronchial allergen challenge. Am Rev Respir Dis 1992; 145: 900-905.

85. Proud D, Siekierski E, Bailey G. Identification of human lung mast cell kininogenase as tryptase and relevance of tryptase kininogenase activity. Biochem Pharmacol 1988; 37: 1473-1480.

86. Regoli D, Barabé J. Pharmacology of bradykinin and related kinins. Pharmacol Rev 1980; 32: 1-46.

87. Geppetti P. Sensory neuropeptide release by bradykinin: mechanisms and pathophysiological implications. Regul Pept 1993; 41: 232-238.

88. Ichinose M, Belvisi MG, Barnes PJ. Bradykinin-induced bronchoconstriction in guinea-pig in vivo: role of neural mechanisms. J Pharmacol Exp Ther 1990; 253: 594-599.

89. Lotvall J, Tokuyama K, Barnes P, Chung K. Bradykinininduced airway microcirculation leakage is potentiated by captopril and phosphoramidon. Eur J Pharmacol 1991; 200: 211-217.

90. Ichinose M, Barnes P. The effect of peptidase inhibitors on bradykinin-induced bronchoconstriction in guineapigs in vivo. Br J Pharmacol 1990; 101: 77-80.

91. Proud D, Reynolds CJ, Lacapra S, Kagey-Sobotka A, Lichtenstein LM, Naclerio RM. Nasal provocation with bradykinin induces symptoms of rhinitis and a sore throat. Am Rev Respir Dis 1988; 137: 613-616.

92. Fuller R, Dixon C, Cuss F, Barnes P. Bradykinin-induced bronchoconstriction in humans: mode of action. Am Rev Resp Dis 1987; 135: 176-180.

93. Ichinose M, Nakajima N, Takahashi T, Yamauchi H, Inoue $\mathrm{H}$, Takashima T. Protection against bradykinin-induced bronchoconstriction in asthmatic patients by neurokinin receptor antagonist. Lancet 1992; 340: 1248-1251.

94. Lei YH, Barnes PJ, Rogers DF. Mechanisms and modulation of airway plasma exudation after direct inhalation of cigarette smoke. Am J Respir Crit Care Med 1995; 151: 1752-1762.

95. Calvet JH, D'Ortho MP, Jarreau PH, Levame M, Harf A, Macquin-Mavier I. Glucocorticoids inhibit sulfur mustard-induced airway muscle hyperresponsiveness to substance P. J Appl Physiol 1994; 77: 2325-2332.

96. Roisman GL, Dusser DJ. Hydrogen peroxide inhibits 
lung neutral endopeptidase. Exp Lung Res 1995; 21: 215225.

97. Borson DB, Gruenert DC. Glucocorticoids induce neutral endopeptidase in tranformed human tracheal epithelial cells. Am J Physiol 1991; 260: L83-L89.

98. Piedimonte G, McDonald DM, Nadel JA. Neutral endopeptidase and kininase II mediate glucocorticoid inhibition of neurogenic inflammation in the rat trachea. J Clin Invest 1991; 88: 40-44.

99. Brokaw JJ, Werner LM, Miller R, White GW. Effect of dexamethasone treatment on the regional distribution of neutral endopeptidase activity in the rat trachea. $\mathrm{Neu}$ ropeptides 1995; 29: 273-280.

100. Painter RG, Dukes RG, Sullivan J, Carter R, Erdos EG, Johnson AR. Function of neutral endopeptidase on the cell membrane of human neutrophils. J Biol Chem 1988; 263: 9456-9461.

101. Shipp MA, Tarr GE, Chen CY, et al. CD10/neutral endopeptidase 24.11 hydrolyzes bombesin-like peptides and regulates the growth of small cell carcinomas of the lung. J Clin Invest 1991; 88: 10662-10666.

102. Aguayo SM, Miller Y, Boose D, et al. Nonconstitutive expression of the gastrin-releasing peptide autocrine growth system in human small cell lung carcinoma NCI-H345 cells. Cell Growth Differ 1996; 7: 563-572.
103. Black PN, Gathei MA, Takahashi K, et al. Formation of endothelin by cultured airway epithelial cells. FEBS Lett 1989; 255: 129-132.

104. Uchida Y, Ninomiya H, Saotome M, et al. Endothelin, a novel potent vasoconstrictor peptide as potent bronchoconstrictor. Eur J Pharmacol 1988; 154: 227-228.

105. Advenier C, Sarria B, Naline E, Puybasset L, Legente V. Contractile activity of three endothelins (ET-1, ET-2 and ET-3) on the human isolated bronchus. Br J Pharmacol 1990; 100: 168-172.

106. Vijayaraghvan J, Scicli AG, Carretero OA, Slauther C, Moomaw C, Hersh LB. The hydrolysis of endothelins by neutral endopeptidase 24.11 (enkephalinase). J Biol Chem 1990; 265: 14150-14155.

107. Di Maria GU, Katayama M, Borson BD, Nadel JA. Neutral endopeptidase modulates endothelin-1-induced airway smooth muscle contraction in guinea-pig trachea. Regul Pept 1992; 39: 137-145.

108. Yang Q, Battistini B, D'Orléans-Juste P, Jeng AY, Sirois P. Modulation of endothelin production and metabolism in guinea-pig tracheal epithelial cells by peptidase inhibitors. Am J Respir Crit Care Med 1997; 155: 1884-1889

109. Chanez P, Vignola, AM, Springall DR, et al. Endothelin and airway cells in asthma. Am Rev Respir Dis 1993; 147: $517-522$. 